\title{
THE EFFECT OF ALLOGENIC FREEZE DRIED PLATELET-RICH PLASMA IN RESPONSES INFLAMMATION REACTION OF RABBIT
}

\author{
Trio Rachmawati ${ }^{1}$, Sri Puji Astuti ${ }^{1}$, Purwati ${ }^{1,2}$ \\ ${ }^{1}$ Department of Biology, Faculty of Science and Technology, Airlangga University Surabaya, East \\ Java, Indonesia \\ ${ }^{2}$ Stem Cell Research and Development Center, Universitas Airlangga Surabaya, East Java, Indonesia
}

\begin{abstract}
This study aims to analyze the effects of allogenic freeze dried platelet-rich plasma in responses inflammation reaction of rabbit. The designs of this study are one group pretest posttest conducted to determine the effect of freeze drying on levels of TGF- $\beta 1$ PRP and post test only control group design conducted to determine the effect of allogenic freeze dried PRP. Nine samples of PRP which examined levels of TGF- $\beta 1$ before and after freeze drying were obtained from blood centrifugation of three rabbits. These nine samples were used as allogenic donor which injected intramuscularly in nine rabbits for the treatment groups. The control group used nine rabbits which was injected intramuscularly using autologous PRP. Both groups were observed inflammatory response. Measurement of TGF- $\beta 1$ levels before and after freeze drying were tested statistically using $\mathrm{T}$ - test dependent. Data inflammatory response were tested statistically using $\mathrm{T}$ - test independent. The results showed that no effect of freeze drying process on levels of TGF- $\beta 1$. Allogenic freeze dried PRP did not cause an iflammatory response.
\end{abstract}

Keywords : autologous, allogenic, freeze dried platelet rich plasma, transforming growth factor- $\beta 1$.

\section{INTRODUCTION}

The use of platelet-rich plasma (PRP) in tissue regeneration has developed as the more number of research and application in the clinical. Platelets are fragments formed cytoplasm of megakaryocytes in the bone marrow. Platelets are the smallest parts of the blood cells, round or oval and with no core, but contain a number of organelles. The structure consists of mitocondria, microtubules and 50-80 grains of granules $(\alpha, \delta, \lambda)$. A granular $\alpha$ has more than 30 bioactive proteins, chemokines and various growth factors such as Transforming Growth Factor (TGF- $\beta$ ), Platelet Derived Growth Factor (PDGF), Vascular Endothelial Growth Factor (VEGF), Insulin-like Growth Factor (IGF), Fibroblast Growth Factor (FGF) (Harrison and Cramer., 1993). These growth factors can be used for tissue repair therapies in various branches of medicine such as oral surgery, plastic surgery, craniofacial surgery, cardiac surgery, orthopedies, neurology, sports medicine, and dermatology (Flanders and Burmester., 2002). 
In the case of tissue repair, growth factor such as TGF- $\beta$ stimulates fibroblasts and increases extra cellular matrix formation (ECM). Transforming Growth Factor $-\beta$ also increases collagens for wound healing process. Other growth factor such as PDGF also functions in the repair of bone tissue by stimulating the production of collagen type1, which induces the synthesis of bone (Koerner et al., 2008). In the process of tissue repair tendon IGF can stimulate the proliferation and differentiation of myeloblast (Harmon., 2010).

In general, platelets are used for clinical applications derived from the patient's own (autologous). The use of autologous products can eliminate immunologic reactions and disease transmission (Alsousou et al., 2009). However, autologous therapy cannot be performed in patients with a deficiency or abnormality of platelet function. This leads to the use of autologous in large variability, because the platelet concentration varies between individuals. Thus, it is difficult to evaluate the results scientifically (Rozman, 2002). Some patients also do not have the courage to do blood sampling in large numbers. Therefore, the use of allogenic PRP (derived from other individuals within a species) is needed as an alternative to growth factor therapy.

This study aims to analyze the effects of allogenic freeze-dried platelet-rich plasma in immunological responses of rabbits. The immunological response were observed from inflammatory response.

\section{MATERIALS AND METHODS}

This study was conducted under permission of Animal Care and Use Committee (ACUC) Airlangga University. The first step was using nine samples of PRP with measured TGF $-\beta 1$ before and after freeze drying process. The second step was with two groups, control and treatment groups. The control group used nine rabbits injected intramuscularly using autologous PRP whereas the nine rabbits in the treatment group were injected intramuscularly using allogenic freezedried PRP. Inflammatory response were observed in both groups. Measurement of TGF- $\beta 1$ levels before and after freeze drying were tested statistically using dependent $\mathrm{T}$ - test, while that of the independent was employed for statistically testing data of inflammatory response and increasing levels of IgM.

\section{RESULTS}

\section{Levels of TGF - $\beta 1$ Before and After Freeze Drying Process}

The results showed that the highest level of TGF- $\beta 1$ at PRP before freeze drying process was $232 \mathrm{pg} / \mathrm{ml}$ and that of the lowest was 136 $\mathrm{pg} / \mathrm{ml}$, with the mean of $178 \mathrm{pg} / \mathrm{ml}$ and SD $\pm 27 \mathrm{pg} / \mathrm{ml}$. Meanwhile, the highest level of TGF- $\beta 1$ in PRP after freeze drying process was $192 \mathrm{pg} / \mathrm{ml}$ and the lowest was $124 \mathrm{pg} /$ $\mathrm{ml}$, with the mean of $162 \mathrm{pg} / \mathrm{ml}$ and SD $23 \mathrm{pg}$ / ml. From statistical decision of $0.081>0.05$, it can be concluded that the level of TGF- $\beta 1$ in PRP before and after freeze drying process was not significantly difference. 


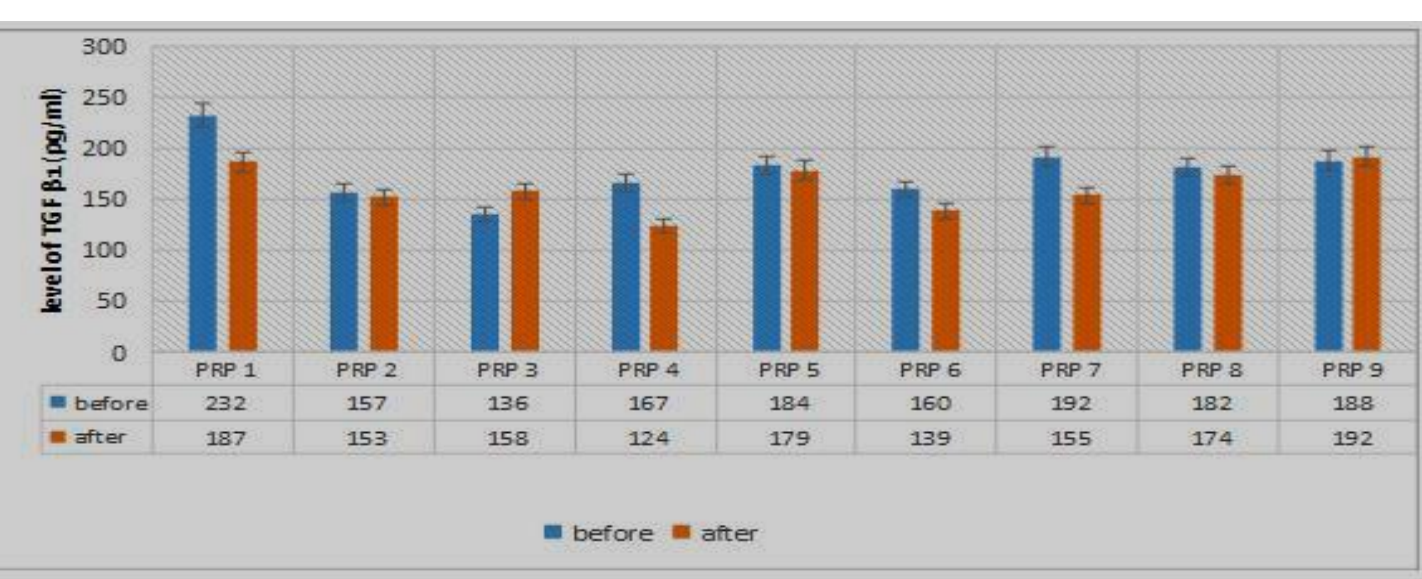

Figure1: Levels of TGF - $\beta 1$ Before and After Freeze Drying Process

\section{Evaluation of inflammatory reactions}

Table 1. Data rabbit body temperature control and treatment groups after intramuscular injection

\begin{tabular}{|c|c|c|c|c|c|c|c|c|c|}
\hline $\begin{array}{l}\text { Autologous } \\
\text { PRP }\end{array}$ & $\begin{array}{c}\text { Control } \\
1\end{array}$ & $\begin{array}{c}\text { Control } \\
2\end{array}$ & $\begin{array}{c}\text { Control } \\
3\end{array}$ & $\begin{array}{c}\text { Control } \\
4\end{array}$ & $\begin{array}{c}\text { Control } \\
5\end{array}$ & $\begin{array}{c}\text { Control } \\
6\end{array}$ & $\begin{array}{c}\text { Control } \\
7\end{array}$ & $\begin{array}{c}\text { Control } \\
8\end{array}$ & $\begin{array}{c}\text { Control } \\
9\end{array}$ \\
\hline $\begin{array}{l}\text { Body } \\
\text { temperature } \\
\left({ }^{U} \mathrm{C}\right) \\
\end{array}$ & 38.5 & 38.3 & 39.1 & 38.8 & 39.1 & 39.2 & 38.9 & 38.3 & 38.5 \\
\hline $\begin{array}{l}\text { Allogenic } \\
\text { freeze dried } \\
\text { PRP }\end{array}$ & $\begin{array}{c}\text { Treatme } \\
\text { nt } 1\end{array}$ & $\begin{array}{c}\text { Treatme } \\
\text { nt } 2\end{array}$ & $\begin{array}{c}\text { Treatme } \\
\text { nt } 3\end{array}$ & $\begin{array}{c}\text { Treatme } \\
\text { nt } 4\end{array}$ & $\begin{array}{l}\text { Treatme } \\
\text { nt } 5\end{array}$ & $\begin{array}{c}\text { Treatme } \\
\text { nt } 6\end{array}$ & $\begin{array}{c}\text { Treatme } \\
\text { nt } 7\end{array}$ & $\begin{array}{c}\text { Treatme } \\
\text { nt } 8\end{array}$ & $\begin{array}{c}\text { Treatme } \\
\text { nt } 9\end{array}$ \\
\hline $\begin{array}{l}\text { Body } \\
\text { temperature } \\
\left({ }^{U} \mathrm{C}\right)\end{array}$ & 39.3 & 38.5 & 39.2 & 38.9 & 38.7 & 39.2 & 38.5 & 38.6 & 39.1 \\
\hline
\end{tabular}

Referring to data on rabbit body temperature in control and treatment groups after intramuscular injection, statistical results were $0,379>0.05$ meaning that there was no difference in body temperature in the control group (autologous) and treatment group (freezedried allogenic PRP). Thus, the use of allogenic freezedried PRP did not cause inflammatory reactions / inflammation.

\section{DISCUSION}

Allogenic PRP used in this study first performed the process of freeze drying. The purpose of the freeze drying process is to preserve the content of growth factors contained in PRP. Several studies have been conducted to determine the advantages of the use of freeze drying in the process of preserving a material or substance which is susceptible to heat like growth factor of TGF$\beta 1$. Another study showed that freeze drying process did not affect the concentration of TGF- $\beta 2$ contained in the freeze- dried amniotic membrane. This is evidenced from the results of this research showing no significant difference between the concentrations of total TGF- $\beta 2$ in the form of fresh amniotic membrane and freeze-dried (Baradaran et al., 2007).

Although platelet is not a cell with a nucleus, the membrane surface contains a number of family immune molecules such as MCH Class I, Fc receptors and complement binding site. Platelet membrane also contains 
antigens of human platelet antigen (HPA) and antigen of polysaccharide $\mathrm{ABO}$ blood type to another, where it was very important in blood transfusion system (Rozman, 2002). Based on the theory of the use of allogenic platelets, it can cause an immune response.

Zhang have proposed that allogenic PRP used in gel PRP did not increase immune response. There were no increase in the level of $\mathrm{CD} 4$ and $\mathrm{CD} 8$, so it may cause the gel covered surface of platelet contains HPA (Zhang, 2013). Allogenic PRP used in this study first conducted the process of freeze drying. The existence of the freezing process $830 \mathrm{C}$ for 24 hours in freeze drying process raised an assumption that it can damage the structure of immunoglobulin protein molecules and antigen found on the surface of the platelet membrane. So, the non reactive antigens did not cause an inflammatory response.

\section{CONCLUTION}

Regarding this, the product allogenic freeze dried PRP is safe for clinical applications.

\section{REFERENCE}

1. Alsousou J, Thompson M, Hulley P, Noble A, Willett K; The biology of platelet-rich plasma and its application in trauma and orthopaedic surgery A Review Of The Literature. Journal of Bone \& Joint Surgery, 2009;91(8): 987-996.

2. Flanders KC, Burmester JK; Medical Aplications of Transforming Growth Factor $-\beta$. Clinical Medicine \& Research, 2002; 1(1):1320

3. Harrison P, Cramer EM; Platelet alpha granules. Blood rev, 1993; 7(1):52-62,
4. Harmon KG; Muscle injuries and PRP: what does the science say?. British journal of sports medicine, 2010; 44(9):616-617.

5. Koerner J, Abdelmessieh P, Azad V, Szczepanowski K, Lin SS, Pinzur M; PlateletRich Plasma and Its Uses in Foot and Ankle Surgery. Techniques in Foot \& Ankle Surgery, 2008;7(2):72-71.

6. Rožman $\mathrm{P}$; Platelet antigens. The role of human platelet alloantigens (HPA) in blood transfusion and transplantation. Transplant immunology, 2002; 10(2):165-181.

7. Baradaran-Rafii A, Aghayan HR, Arjmand B, Javadi MA; Amniotic membrane transplantation. Journal of Ophthalmic \& Vision Research, 2007; 2(1):58-75.

8. Zhang ZY, Huang AW, Fan JJ, Wei K, Jin D, Chen B, Pei G; The potential use of allogeneic platelet-rich plasma for large bone defect treatment: immunogenicity and defect healing efficacy. Cell transplantation, 2013; 22(1):175187. 